\title{
MANAJEMEN USAHA SEBAGAI UPAYA MENINGKATKAN KINERJA KEUANGAN BAGI USAHA KECIL MAKANAN DI LINGKUNGAN STIE EKUITAS
}

\author{
Dwi Puryati \\ dwi.puryati@ekuitas.ac.id \\ Susinah Kuntadi \\ susikuntadi@gmail.com \\ Siska Willy \\ siska_msws@yahoo.com
}

\section{SEKOLAH TINGGI ILMU EKONOMI EKUITAS}

\begin{abstract}
ABSTRAK
Peranan Usaha Kecil Menengah sangatlah penting dalam perkembangan perekonomian suatu negara termasuk di Indonesia, UKM tumbuh cepat sejak tahun 1998, namun begitu ternyata UKM di Indonesia masih belum mampu menghadapi persaingan. Begitupun dengan perkembangan jumlah UKM khususnya yang bergerak dalam bidang kuliner di sekitar STIE Ekuitas sudah banyak tapi belum maksimal dalam perkembangan usahanya apalagi untuk bersaing dengan UKM yang sudah dikelola dengan baik. Tujuan pengabdian ini adalah memberikan pemahaman pengelolaan keuangan, pemasaran secara online dan kebersihan pada usaha kuliner serta bagaimana pengurusan ijin PIRT (Pangan Industri Rumah Tangga) bekerjsaama dengan dinas kesehatan. Dari pengabdian ini, peserta UKM yang bergerak dalam bidang kuliner disekitar STIE Ekuitas merasa sangat puas sebanyak $77 \%$, puas sebanyak $17 \%$ dan sisanya $6 \%$ merasa cukup puas. Mereka memperoleh pengetahuan tentang pengelolaan usaha makanan dan pengurusan ijian PRIT, pengelolaan keuangan dan manajemen pemasaran. Dari hasil pengabdian ini, sebanyak 3 peserta sudah melakukan pengurusan PRIT dan terjadi peningkatan omset dan kinerja keuangan pada beberapa UKM.
\end{abstract}

Kata kunci: Higienitas, Keuangan ,Pemasaran, PIRT.

\section{PENDAHULUAN}

Usaha kecil, dan menengah memiliki peranan yang sangat besar dalam pembangunan dan pertumbuhan ekonomi suatu bangsa. Tidak hanya di negara-negara berkembang seperti di Indonesia, tetapi juga di negara-negara yang sudah dikategorikan maju seperti di negara-negara Eropa, Jepang, dan Amerika Serikat. Di Indonesia sendiri, peran UKM sangat penting, terutama sebagai sarana ketersediaan lapangan kerja bagi jumlah penduduk Indonesia yang di atas 200 juta penduduk. Kemampuan untuk bertahan usaha kecil menengah sudah teruji saat krisis 1998, perusahaan berskala besar banyak yang bangkrut namun UKM tetap mampu bertahan. Mereka mampu bertahan dalam kondisi krisis namun perkembangan usaha 
tidak menunjukkan perkembangan sesuai harapan.

Menurut Direktur Pasar ukmjabar.com, Dani Umar Fauzi, usaha mikro, kecil, dan menengah (UMKM) di Jawa Barat masih sulit berkembang, sedikitnya karena empat masalah ekonomi. Yaitu (1) nilai ekonominya kurang kompetitif di pasaran, (2) kapasitas produksinya masih kurang (3) keterbatasan pemasaran, (4) keterbatasan modal, salah satunya karena tidak bankable. Sedangkan CEO Pro Indonesia Foundation, Budi Satria Isman bilang, sejak tahun 2010 terdapat enam masalah pokok yang menghalangi UKM untuk menaikkan kelas usahanya. Keenam poin tersebut yakni pengetahuan, pemasaran, permodalan, teknologi, legal maupun administrasi keuangan, dan jaringan.

STIE Ekuitas berada di lokasi yang sangat strategis dan di pusat perkantoran, sehingga banyak pelaku usaha kecil di sekitar STIE Ekuitas. Di dalam kampus STIE Ekuitas sendiri terdapat lebih 10 pelaku usaha termasuk KOPMA dan UKM binaan STIE Ekuitas. Sedangkan supplier barang KOPMA sendiri banyak, ada sekitar 20 orang. Semua unit usaha tersebut bergerak di bidang produksi dan penjualan makanan. Dari survey pendahuluan diperoleh informasi bahwa kondisi usaha mereka dalam beberapa tahun ini tidak mengalami perkembangan yang signifikan, bahkan beberapa unit usaha mengalami penurunan omset penjualan dan penurunan keuntungan. Artinya usaha kecil di sekitar STIE Ekuitas pun mengalami permasalahan yang sama seperti yang diuangkapkan Direktur Pasar UKM dan CEO Pro Indonesia Foundation. Sebagai contoh KOPMA STIE Ekuitas dalam tiga tahun terakhir mengalami penurunan kinerja keuangan dan masalah yang dihadapi antara lain kesulitan dalam melakukan tertib adminsitrasi dan menyusun laporan keuangan serta bagaimana memanaje uang yang ada dengan optimal. Kinerja keuangan KOPMA STIE Ekuitas selama tiga tahun terakhir mengalami penurunan yaitu $11,78 \%$ pada tahun 2016 dan 19,00\% pada tahun 2017 . Sedangkan asset KOPMA mengalami penurunan 22,46\% pada tahun 2016 dan 26,18\% pada tahun 2017.

Kalau KOPMA yang pengurusnya adalah mahasiswa yang relative lebih terdidik dan memiliki pengetahuan lebih dibanding pelaku usaha kecil lainnya saja menghadapi masalah, apalagi pelaku usaha kecil lainnya. Selain itu rata-rata pelaku usaha makanan tersebut belum memiliki pengetahuan memadai tentang aspek kesehatan pembuatan maupun penyajian makanan dan belum memiliki ijin PIRT (Pangan Industri Rumah Tangga).

Dengan kondisi inilah kami tim dosen STIE Ekuitas dengan bekerja sama dengan Dinas Kesehatan Kota Bandung bermaksud melakukan pengabdian untuk membantu meningkatkan kinerja keuangan Usaha kecil di lingkungan STIE Ekuitas. Kegiatan pengabdian ini direncanakan dengan memberikan materi terkait permasalahan usaha kecil sesuai dengan keahlian masingmasing yang meliputi pelatihan manajemen keuangan, pencatatan sederhana, penyusunan laporan keuangan, pemasaran produk, dan higienietas produk makanan serta pengurusan ijin PIRT.

Berdasarkan data tersebut diatas, menjadi latar belakang penulis untuk melakukan pengabdian masyarakat berupa pelatihan mengenai pengurusan ijin PIRT, pelatihan pemasaran dan pelatihan penyusunan laporan keuangan sederhana.

Berdasarkan latar belakang di atas, penulis dapat merumuskan tujuan kegiatan pengabdian sebagai berikut: 
1. Akuntansi, diberikan pelatihan mengenai pembukuan sederhana, pengelolaan keuangan dan penyusunan laporan keuangan.

2. Pemasaran, diberikan materi strategi pemasaran produk dengan menggunakan media social.

3. Higeinitas produk makanan, diberikan materi bagaimana membuat dan menyajikan makanan dengan sehat dan materi pengurusan ijin PIRT.

\section{METODOLOGI PELAKSANAAN}

Tahapan kegiatan pelaksanaan Pengabdian pada Masyarakat ini terdiri dari tahap persiapan awal, tahapan pelaksanaan dan tahapan akhir dengan rincian sebagai berikut:

1. Tahapan Awal Persiapan Kegiatan Pengabdian Pada Masyarakat

a. Berdiskusi dengan pelaku usaha kecil di lingkungan STIE

b. Menyebarkan kuesioner tentang masalah yang dihadapi dan pemahaman manajemen usaha

c. Mempersiapkan bahan-bahan pelatihan dan pendekatan terhadap pelaku usaha kecil dan koperasi di lingkungan STIE Ekuitas

d. Koordinasi dengan Dinas Kesehatan tentang waktu dan materi pelatihanMelakukan diskusi dengan mitra mengenai kendala yang dihadapi baik dalam proses produksi maupun dalam manajemen.

2. Tahapan Pelaksanaan Kegiatan Pengabdian Pada Masyarakat

a. Pelatihan pembukuan sederhana, pengelolaan keuangan dan penyusunan laporan keuangan

b. Pelatihan Pemasaran

c. Pelatihan Higenitas produk dan pengurusan PIRT

3. Tahapan Akhir Kegiatan Pengabdian Pada Masyarakat

a. Hasil atau Luaran Pengabdian

b. Monitoring dan Evaluasi

\section{HASIL DAN LUARAN}

\section{Tahapan Awal}

Hasil pelaksanaan kegiatan yang pertama adalah koordinasi dengan pihak Dinas Kesehatan Kota Bandung untuk peningkatan kinerja UMKM mitra STIE Ekuitas melalui higienitas produk dan pengurusan PIRT. Pihak dari Dinas Kesehatan Kota Bandung memberikan materi bagaimana menentukan produk yang higienis pada saat akan dipasarkan dan cara melakukan pengurusan PIRT.

Selanjutnya melakukan pendekatan terhadap UMKM mitra STIE Ekuitas yang terdiri dari UMKM supplier dari KOPMA, mahasiswa studpeneur STIE Ekuitas dan pengelola kantin STIE Ekuitas untuk menggali lebih dalam lagi permasalahan yang dihadapi pelaku UMKM makanan dengan hasil sebagai berikut:

1) KOPMA STIE Ekuitas : Kesulitan melakukan pencatatan secara sistematis dan berkelanjutan dan penyusunan laporan keuangan, prosedur yang harus ditempuh KOPMA agar produk yang dimasukkan ke KOPMA higienis

2) Mahasiswa Studpreneur : Kesulitan melakukan pelabelan dan cara mengecek higienitasnya jika usaha yang dilakukan mengemas makanan, dan menghitung harga pokok serta menentuakan harga jual

3) Dari Supplier KOPMA STIE Ekuitas : kesulitan mengurus PRIT dan sertifikat produk khususnya untuk produk susu dan turunannya tidak bisa didaftarkan PIRT. Pemasaran secara online karena keterbatasan menggunkan media komputer atau HP.

4) Dari Pengelola Kantin:

5) Kesulitasn melakukan pencatatan setiap hari, dan cara menghitung laba usaha jika banyak penjualan yang belum dibayar, cara memisahkan uang sendiri dengan using usaha. 


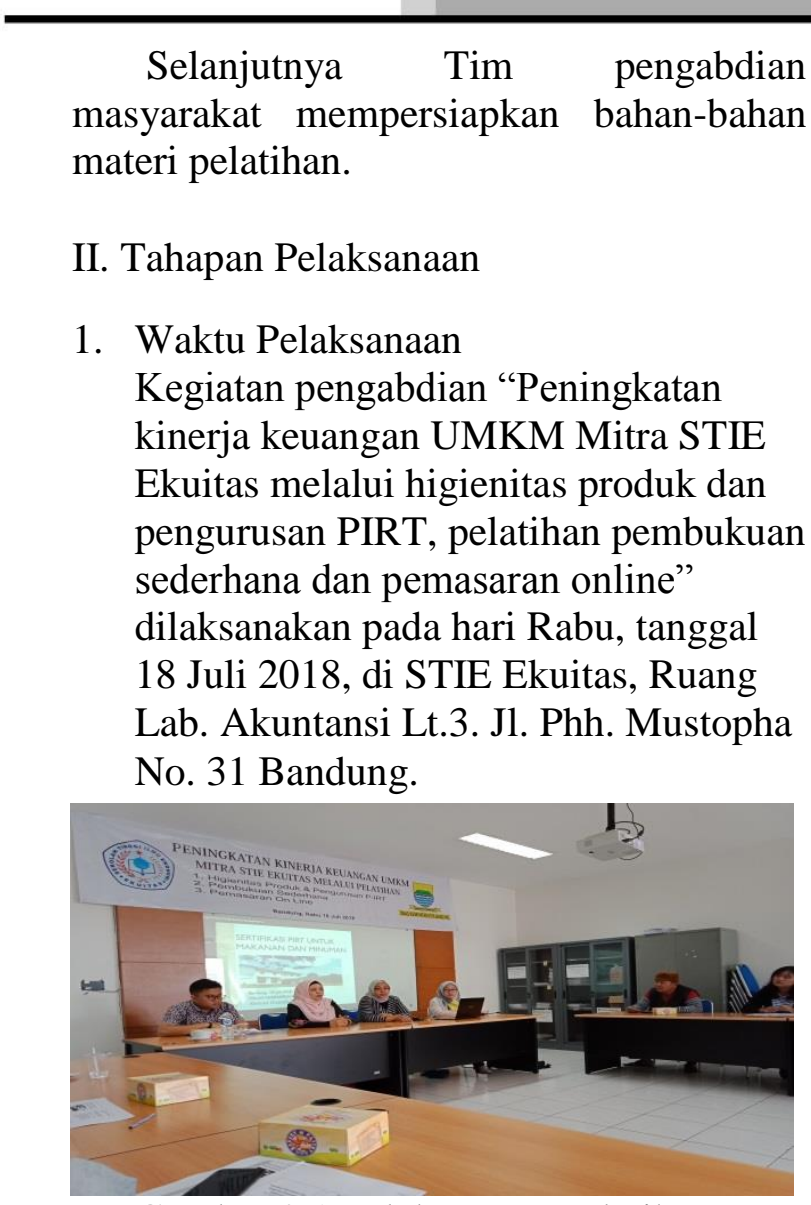

Gambar 2.1 Pelaksanaan Pelatihan

\section{Peserta}

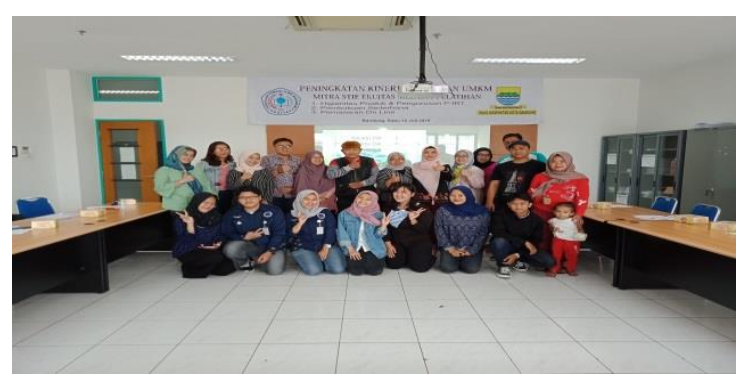

Gambar 2.2 peserta pelatihan

Kegiatan pengabdian dihadiri oleh 18 orang peserta yang merupakan UMKM mitra STIE Ekuitas.

3. Materi Pengabdian dan Nara Sumber Materi pelatihan disampaikan oleh tim pengabdian masyarakat dan bekerjasama dengan staf ahli dari Dinas
Kesehatan Kota Bandung sebagai berikut:

a. Dwi Puryati, SE., M.Si., Ak., CA dan Siska Willy, SE., M.Ak., Ak., CA memberikan materi Pengelolaan Keuangan yang terdiri dari pentingnya pengelolaan Keuangan dan pencatatan sederhana, dan penyusunan laporan keuangan.

b. Susinah Kuntadi, S.Kom., MM memberikan materi pemasaran online meliputi konsep pemasaran, media pemasaran online, dan implementasi pemsaran online dalam UKM

c. Ahmad Gunadi S, S.Farm. Apt memberikan materi tentang Higienitas Produk dan PRIT, meliputi ciri produk higinies, proses produksi dan higineitas, pentingnya PRIT, dan prosedur pengurusan PIRT Makanan dan Minuman

\section{Tahapan Akhir}

1. Hasil atau Luaran Pengabdian

a. Peningkatan pemahaman para peserta tentang materi yang diberikan meliputi:

1. Higienitas produk dan pengurusan PIRT:

a) Lingkungan proses produksi

b) Bangunan dan fasilitas

c) Peralatan produksi

d) Suplai air atau sarana penyedia air

e) Fasilitas dan kegiatan hygiene dan sanitasi

f) Kesehatan dan hygiene karyawan

g) Pemeliharaan dan program hygiene sanitasi karyawan

h) Pelebelan makanan dan pengemasan

i) Pengurusan PRIT

2. Pengelolaan Keuangan dan Pembukuan sederhana

a) Pengelolaan keuangan 

b) Pembuatan pembukuan sederhana
c) Penyusunan keuangan
laporan

3. Pemasaran online

a) Dapat memasarkan produk di media sosial

b) Dapat membuat iklan produk yang menarik minat pelanggan

Hasil kuesioner menunjukkan peserta sangat puas sebanyak $77 \%$, puas sebanyak $17 \%$ dan sisanya 6 $\%$ merasa cukup puas. Kepuasan di sini mengandung makna puas terhadap kegiatan pelatihan dan mengerti tentang materi yang diberikan.

b. Peningkatan minat pelaku UMKM untuk mengurus PRIT. Sudah ada 3 pelaku UMKM yang memiliki PRIT.

\section{c. Peningkatan omset penjualan pelaku UMKM antara 5-15\% dari omset sebelum mengikuti pelatihan.}

\section{Monitoring dan Evaluasi}

Kegiatan monitoring dan evaluasi dilakukan selama tiga bulan untuk memonitor implementasi hasil pelatihan dan pendampingan pelaku UKM.

\section{KESIMPULAN}

1. Pengabdian kepada masyarakat yang dilakukan pada KOPMA dan UKM binaan STIE Ekuitas untuk membantu meningkatkan kinerja keuangan Usaha kecil di lingkungan STIE Ekuitas. Kegiatan pengabdian ini memberikan materi terkait permasalahan usaha kecil sesuai dengan keahlian masing-masing yang meliputi pelatihan pengelolaan

$\begin{aligned} & \text { keuangan, pencatatan sederhana, } \\ & \text { penyusunan laporan } \\ & \text { keuangan, }\end{aligned}$
pemasaran produk secara online, dan
higienietas produk makanan serta
pengurusan ijin PIRT.

2. Pelaku UMKM memperoleh manfaat berupa peningkatan pemahaman tentang pengelolaan keuangan, pemasaran online, higienitas produk makanan dan minuman, dan pengurusan PRIT.

3. Pelaku UMKM mengalami peningkatan omset dan keuntungan usaha.

\section{DAFTAR PUSTAKA}

Susanto, Joni wong. (2010), Internet Marketing for Beginners, Elex Media Komputindo.

Warsono, Soni. (2017). Akuntansi UMKM: AB Publisher Yogyakarta.

https://bisnisbandung.com/2017/09/02/mas alah-utama-ukm-sulit-tumbuh/

https://www.pikiranrakyat.com/ekonomi/2016/05/11/inialasan-umkm-jabar-sulit-maju368842

http://www.wirausahabarujabar.net/ http://panduanim.com/social-mediamarketing/. 